Wales and the Britons of the North

Author(s): Professor Anwyl

Source: The Celtic Review, Vol. 4, No. 14 (Oct., 1907), pp. 125-152

Published by:

Stable URL: http://www.jstor.org/stable/30069930

Accessed: 28-10-2015 05:44 UTC

Your use of the JSTOR archive indicates your acceptance of the Terms \& Conditions of Use, available at http://www.jstor.org/page/ info/about/policies/terms.jsp

JSTOR is a not-for-profit service that helps scholars, researchers, and students discover, use, and build upon a wide range of content in a trusted digital archive. We use information technology and tools to increase productivity and facilitate new forms of scholarship. For more information about JSTOR, please contact support@jstor.org. 
young men and girls stood grouped in the shadows, and women spoke low in each other's ears. And so another hour passed, and the great fire sank. For a moment the golden sparks danced on the dark as the red logs fell, then the hedgerows blended into the darkness, the figures by the bank grew vague, and night curtained us around.

And, lo! before we had fully realised that the night had fallen there was the dawn. And as the stars were quenched, and the boys leapt over the embers of the fire,-as in far gone ages their forefathers had driven their cattle throughwe rose and welcomed the shining face of Lugh.

\section{WALES AND THE BRITONS OF THE NORTH}

\section{Professor Anwyl}

THE object of the present paper is not to attempt an exhaustive account of the Brythonic section of the ancient population of Scotland, but to gather together as many as possible of those scattered links which unite the history of Wales to that of the Ancient Britons of the North, so far as these links are discoverable in the literature of Wales and in documents related to it. It is the hope of the writer that a succinct and accessible account of this kind may be the means of awakening fresh interest in the subject, and be of service as a stimulus and basis to further investigation. In both districts there are questions of great interest, not only in the domain of pre-Roman archæology, but also in the important sphere of the relations of the Roman to the pre-Roman civilisation. The inter-relations of Late-Celtic and Roman culture are deserving of the closest study, if we are to have a true view of Britain in the Roman period, and not less important is research into the lines of 'Roman' trade which affected districts that were not technically within the bounds of the Empire. In both districts, again, there is a good field for study in a comparison of place-names, in spite of the complications produced by Gaelic and English influences in the 
south of Scotland. The traces of Brythonic numerals, which have been ably investigated by Mr. David MacRitchie and others, also deserve attention. In so obscure a subject every ray of light may help to diminish the gloom. Nor is it possible to overlook the evidence that may accrue from the early ecclesiastical history of Wales and Scotland. The name of St. Kentigern alone links Glasgow and St. Asaph; and the students of Welsh hagiology know only too well that this is not by any means the only link between the Christians of Wales and their brethren of the North. In view of the distance between Wales and Southern Scotland, it seems strange that there should be such links, but nothing is clearer to the student of early Welsh literature and of the genealogies of the princely families of Wales than that they are very real. Certain Welsh families whose genealogies have been preserved (as, for example, the pre-Norman genealogies called the 'Harleian'), styled themselves even in the Middle Ages ' Gwyr y Gogledd' or 'The Men of the North,' and the early Welsh poetry which is based on their traditions make the North the chief scene of their exploits. A valuable genealogical document of the Middle Ages (Hengwrt MS. 536) is entitled 'Bonedd Gwyr y Gogledd yw hyn' ('This is the genealogy of the Men of the North'). It may be seen with a translation in Skene's Four Ancient Books of Wales, vol. ii. In the same manuscript is contained another document entitled 'Trioedd Arthur a'i wyr' ('The triads of Arthur and his men '), and in this there are the names of several members of the same northern families. There are not a few points of contact also between the oldest Welsh traces of the Arthurian legend and the genealogies in question.

Closely connected, again, with the genealogies are the two manuscripts (A and B) of the Annales Cambriæ, which contain a few references to the affairs of Northern Britain, similar in character to those found in the Irish Annals. For the sake of convenience these references will be given at the outset in chronological order. The portions enclosed in brackets are the additions of MS. B. 
1. 573. Bellum Armterid [inter filios Elifer et Guendoleu filium Keidiau ; in quo bello Guendoleu cecidit: Merlinus insanus effectus est].

2. 580. Guurci et Peretur [filii Elifer] moritur.

3. 626. Etguin baptizatus est, et Run filius Urbgen baptizavit eum. (This statement is a point of contact with Nennius.)

4. 630. Gueith Meiceren (a mistake for Meicen); et ibi interfectus est Etguin cum duobus filiis suis: Catguollaun autem victor fuit.

5. 644. Bellum Cocboy, in quo Oswald rex Nordorum et Eoba rex Merciorum corruerunt.

6. 866. Urbs Ebrauc vastata est: id est cat Dub gint (i.e. the battle of the black heathen, meaning the Scandinavians).

7. 870. Arx Alt Clut a gentilibus fracta est.

8. 946. Strat Clut vastata est a Saxonibus.

These annals also contain the following references to the Picts :-

1. 736. Ougen rex Pictorum obiit.

2. 750. Bellum inter Pictos et Brittones, id est, gueith Mocetauc, et rex eorum Talargan a Brittonibus occiditur. [Teudubr filius Beli moritur.]

3. 776. Cemoyd rex Pictorum obiit.

4. 856. Cemoyth rex Pictorum moritur, et Jonathan princeps Opergeleu moritur.

The references of these Annals to certain Irish personages, who also played a part in the history of Scotland, are of interest.

1. 521. Sanctus Columcille nascitur. Quies sanctae Brigidae.

2. 558. Gabran filius Dungart moritur.

3. 562. Columcille in Brittania exiit.

4. 595. Columcille moritur.

5. 607. [Aidan map Gabran moritur.]

6. 704. Dormitatio Adomnan.

MS. A of the Annales Cambriæ is in the Harleian collection 
No. 3859. The Welsh chronicle called 'Brut y Tywysogion' ('The Chronicle of the Princes') also contains a few references which are practically identical with those of the Annales Cambriæ.

1. Ac yna y bu uar6 beli fab elfin (and then died Beli son of Elfin).

2. Ac yna $y$ bu uar6 owein vrenhin $y$ picteit (and then died Owen King of the Picts).

3. Deg mlyned a deugeint a seith cant oed oet crist pan vu y vr6ydyr r6g y brytanyeit ar picteit yg g6eith maes y da6c ac y llada6d y brytanyeit Talargan brenhin y picteit. (Seven hundred and fifty years was the age of Christ when the contest took place between the Britons and the Picts in the battle of 'maes y da6c,' and the Britons slew Talargan, King of the Picts.)

4. Deg ml. a thrugein ac 6yth cant oed oet crist pan vu kat kryn onnen ac $y$ torret kaer alclut $y$ gan $y$ paganyeit. (Eight hundred and seventy was the age of Christ when the battle of 'Kryn onnen' took place, and the fortress of Alclut was destroyed by the pagans.)

With regard to the Annales Cambriæ, it is stated in the Rolls edition that MS. A is written on vellum in octavo. It belongs to the latter part of the tenth or the beginning of the eleventh century, and is found without a title or introduction in the body of a MS. of Nennius. It is followed immediately by the pedigree of Owain son of Howel the Good, who died in 948. MS. B is described in the Rolls edition as bearing the title 'Annales ab urbe condito ad usque A.D. 1286,' and as being a folio MS. written in triple columns in a hand of the thirteenth century without title or introduction. It is found on certain fly-leaves prefixed to an abridged copy of Domesday Book which is now in the Record Office.

In close conjunction with these references from Annals may be taken those furnished by such expanders of the annalistic framework then used for history as Gildas and Nennius. No attempt will be made in the present paper to deal with 
any of the critical questions connected with these writers. The first of these, Gildas, is generally called in Welsh mediæval writings Gildas fab Caw, i.e. Gildas, son of Caw. Caw (whose name is sometimes Latinised as Caunus) is generally styled Caw o Brydyn, or Caw from Pictland. Caw is also represented as the father of the poet Aneirin, whose name is usually, though less correctly spelt, Aneurin. In Welsh hagiology several of the saints of Anglesey are represented as Caw's children. Sometimes he is said to have ruled over Cwm Cawlwyt, but this name appears only to mean 'the vale of the Blessed Caw,' the adjective 'llwyd,' grey, being frequently used in the older Welsh in the sense of 'blessed.' Returning now to Gildas we find that he tells us that after the departure of the Romans Britain was trodden underfoot by two strange nations, the Picts and the Scots. Against these, he says, the Britons could not hold their own. The combination of the names Picts and Scots is itself not unworthy of attention in the present connection. In consequence of these troubles the Britons are said to have sent messengers to Rome with letters begging with earnest supplications and tears for a host of soldiers to avenge their wrongs, and vowing, if the enemy were driven out of their country, that they would submit for ever afterwards with all their heart to the empire of Rome. Gildas also tells us that the Roman soldiers requested the inhabitants to raise a wall across the island from sea to sea, and to set upon it a sufficient number of soldiers for their protection, and to be a source of terror to the enemies whom they wanted to keep off. But the wall, he says, was made of turf and not of stones, and consequently for a people who were without skill or culture, and without a general to lead them, it was not of much service. It is rather remarkable that it seems to be implied here that the in roads of the Scots as well as the Picts were by land and not by sea. He further says that while that legion was returning home in great joy and jubilation, behold the old enemies again, like ravenous and open-mouthed wolves, grew frenzied with severe famine and leapt over into the fold without a shep-

VOL. IV. 
herd to watch them. In the nineteenth chapter both the Picts and the Scots (apparently in combination) are represented as having rushed ravenously from the boats in which they had sailed over the deep ocean. These two nations, he says, differed to some extent in their habits, but they were both alike in their insatiable desire for the shedding of blood. When they understood that those who aided the Britons had left and refused to return, they took possession more confidently than ever of the whole of the north and of the furthest portions of the land as far as the wall in the place of the previous inhabitants. To oppose these attacks a garrison had been set on the rampart of the Britons, but it was as lacking in energy to fight as it was unfit for flight; it was feeble and cowardly of heart, and was wasting day and night in its foolish watch. The barbarians, too, according to Gildas, were lacking in the clothing of civilisation. He also depicts them as dragging with their hooked weapons the wretched barbarians from the walls and beating them against the ground. The result of the barbarian attacks, he informs us, was that the citizens of Britain were thrown into the utmost disorder and into internal conflicts, until the country lost its whole supply of sustenance. In the twenty-first chapter Gildas describes the Irish marauders as leaving Britain with the intention of again returning, while we are further told that it was then that the Picts first settled on the extreme corner of the island, where they remained plundering and devastating from time to time. Though Gildas does not enter into the detail that one could have wished for as to the relations between the Britons of Wales and those of the North, he evidently keeps his eyes open to events in Wales as well as in the North and names one prince of North Wales, Maglocunos (Maelgwn Gwynedd), the grandson of Cunedda Wledig, a Briton from the North, against whom he inveighs most bitterly. This is all the more remarkable since the Welsh tradition represents Maelgwn Gwynedd as having befriended the family of Caw by giving them land in North Wales. 


\section{WALES AND THE BRITONS OF THE NORTH 131}

The writer who next claims our attention is Nennius, whose work is found in several recensions based ultimately on a small work written by a certain 'filius Urbagen.' The name Urbagen appears to be a doublet (with the connecting vowel preserved, possibly as a neutral vowel, written as ' $a$ ') of the name Urbgen, the older form of Urien, a prominent member of one of the northern British families. The different recensions show distinctly different topographical interests, as, for example, the North Wales recension and that of Builth. It is highly probable that the older nuclei were written in the North, possibly at Dumbarton or Carlisle. In the work of Nennius there are clearly fragments of a life of St. Garmon (in Latin, Germanus), which incorporated certain local stories from Welsh parishes called after their saint Garmon. One of these churches still bears the name St. Harmons, and is situated in the ancient district of Gwrtheyrnion (or the territory of Gwrtheyrn). It is probably from the account of the association of the name Garmon with this district that the name Gwrtheyrn (Vortigern) came into the life of the saint, and through that channel into Nennius. The lives of the Welsh saints almost always described the relations between the saint and some royal personage, as, for instance, Arthur or Maelgwn. In Eifionydd in Carnarvonshire there is another church dedicated to Garmon, called Llanarmon, and a few miles away, and within the same zone of legend, is the valley called Nant Gwrtheyrn (or the vale of Vortigern). Another district which enters into the topography of Nennius is that of Ial (or Yale), where there is also a Llanarmon, commonly known as Llanarmon yn Ial (or Llanarmon in Yale), while further we have Mass Garmon (the plain of Garmon) near Mold. Very valuable work in the analysis of Nennius has been done by Professor Zimmer in his Nennius Vindicatus, and, with special reference to the original nucleus, by $\mathrm{Mr}$. E. W. B. Nicholson.

The references in Nennius which bear upon the present topic are the following:-

1. A reference to the Scots and the Picts as being among 
the four nations that inhabit the isle of Britain. The other two nations mentioned are the Saxons and the Britons.

2. A reference to an island on the extreme boundary of Britain, in addition to the Isle of Wight and the Isle of Man. This island is said to belong to the Picts and to bear the name Orcania. These three islands are said to constitute the 'three isles' of Britain, and reference to them under this name is found in the Welsh Triads.

3. Not less than eight hundred years after the arrival of the Latins (or the descendants of Fneas) in Britain, the Picts are said to have come and taken possession of the islands called 'Orcades'; then, rushing out from the islands they devastated many regions and took possession of the parts that are on the left side (i.e. on the North, designated in Celtic as 'the left') of Britain, and there, Nennius says, they remain to this day in possession of the third part of Britain. The Scots are represented by Nennius as arriving in Ireland at a later date from Spain. The Britons, he says, arrived in Britain in the third age of the world and the Scots in Ireland in the fourth.

4. The Scots 'who are in the West' are said to have united with the Picts from the North, and to have fought incessantly against the Britons, because the Britons were not accustomed to handle arms.

5. An eponymous ancestor of the men of Scotland (Albanus) is represented along with Francus, Romanus and Britto, as the son of Hessitio, son of Alanus, the first of the sons of Japheth to arrive in Europe.

6. There is a reference to the Wall of Severus, where he is said to have built a wall one hundred and thirty-two miles long from sea to sea across Britain. In the tongue of the Britons that wall, we are informed, was called 'Gwal' (generally given as Guaul). $\mathrm{He}$ (Severus) had ordered it to be built between the Britons and the Scots and Picts [the combination should here also be noted] because the Scots from the West and the Picts from the North used to unite to fight against the Britons, since they were at peace with each other. 


\section{WALES AND THE BRITONS OF THE NORTH 133}

7. Three times the generals of the Romans were slain by the Britons, but when the Picts and Scots began to interfere with them they sent to ask for help from the Romans.

8. During the reign of Vortigern the fear of the Picts and Scots, the onset of the Romans, and the terror of Emrys (Ambrosius) weighed heavily on them.

9. Hengist asks Vortigern to give to his son and his brother the districts in the North near the wall that is called Gwal in return for their aid in fighting against the Scots. The northern topography and colouring of the story is very remarkable. They (Octha and Ebissa) with their forty ships come at the invitation of Vortigern. The northern topography is seen further where we are told that Octha and Ebissa, after voyaging around the territory of the Picts, plundered the islands of the Orcades, and came and possessed many districts beyond the 'Frenessic' sea ('which is between us and the Scots') as far as the boundaries of the Picts. The wavering of the tradition between the North and the South suggests that we have in the narrative an amalgamation of two separate legends of the Saxon invasion of Britain emanating from North and South Britain respectively. Perhaps there may be some trace of such amalgamation in the reference to the two names of Thanet, the older of which is said to have been Ruoihin or Ruoihm. The name Octha is curiously like the Welsh name Oeth in the name found in Welsh legend as Caer Oeth or the Fort of Oeth.

10. There is a reference to Carlisle as Lugubalia (the Welsh derivative being Lliwelydd from Lugubalium). In one MS. Vortigern is said to have built near this place the fortress of Guasmoric, in English 'Palmcastre.'

11. In the section called 'the Mighty Deeds of Arthur' there is a further reference to Octha as having crossed from the eastern side of Britain to the kingdom of the men of Kent, and it is from him that the men of Kent are said to have sprung.

Without entering into the very difficult question of Arthurian topography, it may be stated that this section 
on 'the Mighty Deeds of Arthur,' which is found in some MSS. of Nennius, contains undoubted references to North Britain; for example, Arthur's seventh battle is stated to have been fought in the 'Silva Celidonis,' a form equivalent to the Welsh 'Coed Celyddon,' or the wood of Caledonia. Similarly, it is not improbable that by 'Linnuis' is meant 'Lennox,' in the account of the sixth battle, which is said to have been fought near another river called the 'Dubglas' in that district. The river Tribruit (the Trywrwyd of the Arthurian poem in the Black Book of Carmarthen) is thought by the highest authority on Welsh topography, Mr. Egerton Phillimore, to be the Solway Firth, and the expression 'Tratheu' (for Traetheu) Trywruid (the shores of Trywruid) seems to be not inappropriate to that identification. In another MS. of Nennius there is an addition to the same section about Arthur, wherein it is stated that he brought with him from Jerusalem an image of the Virgin Mary, parts of which were kept in great respect in the narrator's day at Wedel (in English, Wedale), the Dale of Woe. Wedale, the narrator says, is a village in the province of Lodonesia (the Lothians) 'now under the authority of the Bishop of St. Andrews, in Scotland, six miles to the west of the ancient and famous monastery of Melrose.' The rivers Glein, Bassas and Guinnionn, given as sites of Arthur's battles, may also be in the North, as well as Mynydd Agned, but this is uncertain.

12. Nennius refers also in the 'Genealogies' to Echfrid, who made war against his cousin 'Birdei,' king of the Picts, but he fell together with all the mighty men of his army, and the Picts and their kings were victorious; and the plunder-loving Saxons never more demanded tribute from the Picts.' Since the time of this battle, it (the battle) is called 'Gweith Lin Garan,' a name, be it observed, which is in form Welsh.

13. In the genealogies of the kings of Deira (in Welsh Deifr), the following points may be noted : $(\alpha)$ That we have a reference to the fall of Etguin (Edwin) in the battle of Meigen, as in the Annales Cambriæ; (b) That the kingdom 
was never restored from his stock, since none of his family escaped from that battle, but were all slain with their father by the army of Cadwallon, the king of the district of Gwynedd; (c) That in this genealogy one epithet, Glinmaur, or 'the large-kneed,' that of Aeta is in Welsh, or at any rate Brythonic. There are also two names of districts given in a Brythonic form, namely, Dinguayrdi (probably for Dinguaryoi or Dinguaruy) and Guurth Berneich. This makes it not improbable that the genealogy was compiled by some Briton of the North, who was interested in the history of the neighbouring Northumbrians.

14. In this part of the narrative are two other paragraphs, probably emanating from the same district. The first tells us that a certain Dutigirn was fighting valiantly against the race of the Angles. At that time, the writer informs us, Talhaern Tataguen (i.e. Tad Awen, the father of the Muse) flourished among the bards, and in the same period also lived Neirin, Taliesin, Bluchbard, and Cian, who was called 'Guenith Guaut,' the 'Wheat of Song.' These had all attained distinction in Welsh poetry. Neirin is undoubtedly Aneirin (usually known as Aneurin), Taliesin is certainly the Welsh poet of that name, but Bluchbard and Cian are unknown in the history of Welsh literature, unless the former name be, as some have supposed, a corruption for Llywarch. The second paragraph, which appears to emanate from the same Northern chronicler, is one which refers to the king of Gwynedd (part of North Wales), Maelgwn, the Maglocunus of Gildas. Of him we are told: 'The powerful King Maelgwn (Maglocunus) was reigning over the Britons, that is, in the region of Gwynedd, since one of his forefathers, Cunedag, with his eight sons, had come from the east of the country, that is, from the region called "Manau Guotodin," a hundred and forty-six years before the reign of Maelgwn, and had driven away the Scots (i.e. the Irish) with great slaughter from those parts, so that they never returned to dwell in them. In the Welsh genealogies Maelgwn appears as Cunedda's greatgrandson. Manau (later Manaw) is doubtless the same name 
as that which exists in the corresponding Goidelic form in Clackmannan and Slamannan, while the name Guotodin (later Gododin) seems beyond reasonable doubt to be identical with

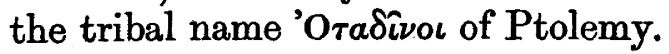

15. In another portion of this section of the Chronicle we find references to other events in the history of the Britons of the North, which tend to gather round the person of Urien Rheged. A certain Hussa is said to have reigned for seven years; further we are told that against him there fought four kings-Urbgen, Riderch hen, Guallauc, and Morcant. It is further stated that Deodric fought valiantly against that Urien and his sons: "And at that time the day was won, sometimes by the enemy, sometimes by our fellow-countrymen, but he blockaded them for three days and three nights in the Island of Metcaud.' When he was on one of his expeditions he was murdered at the instigation of Morcant, because Morcant was jealous of him, in that he excelled all kings in the power of renewing a contest. In this narrative, too, we have a reference to 'Dinguoaroy' under its English name Bebbanburth, which is said to have been so called because Eadfered gave it to his wife Bebbab. We have also a reference to the district of Elmet, which Eoguin possessed, and from which he expelled Certic (probably Ceretic) the king of that region.

16. The next paragraph reveals a curious relationship between Run (later Rhun), son of Urien, and the Angles of the North, for he is represented as a missioner of Christianity. The passage reads: 'At the end of twelve days after Pentecost there was baptized Eanfled his daughter-she and all her followers, both sons and daughters. The following Easter Eadguin also was baptized, and with him there were baptized twelve thousand people. And if any one wishes to know who baptized them, Run, son of Urbgen (Urien), did so, and he did not cease for the space of twelve days from baptizing the whole plunder-loving nation, and many believed in Christ through his work as a preacher.' In Bede, on the other hand, we are told that Eadguin was baptized by Paulinus. 
17. In the next section are other allusions that show that their author was not only interested in Northern affairs, but was also familiar with Welsh. For instance, the epithet here given to Oswald is a Welsh one, namely, Lamnguin (that is, 'he of the bright blade,' mod. Welsh Llafnwyn). He is said to have slain Cadwallon, king of Gwynedd, in the battle of Catscaul, but to have lost at the same time many of his own men. It is difficult to be certain whether the 'Iudeu' mentioned in the same paragraph is in the North or not; but it appears to be identical in form with the name 'Iodeo' of the Book of Aneirin, and possibly with the 'Urbs Giudi' of Bede. The term 'Iodeo' or 'Iudeu' seems to be associated with the Welsh mediæval expression 'Mor Udd' for an older 'Mor Iud,' which was used for the North Sea, and which at an older stage may have been a mere local appellation for 'the Firth of Forth.' A frequent expression in mediæval Welsh to denote the breadth of the island is ' $O$ For Udd hyd For Iwerddon,' which may have originated among the Britons of the North to express 'from the Firth of Forth to the Sea of Ireland.' In the next passage we are informed that Osguid gave back to Penda all the wealth that he had in the city, and that Penda divided it among the kings of the Britons: this distribution, we are further told, was called 'Atbret Iudeu' (the restoration of Iudeu). The term 'Atbret' does not actually occur in Welsh, but it is a perfectly regular Brythonic formation from ad + ber (Welsh adfer), to restore. Further, we are told 'But Catgabail (Cadafael) king of Gwynedd rose in the night, and he alone of his army escaped, and for this he was called Catgabail Catguommed (Cadafael Cadommedd). Ecgfrid, son of Osbiu, reigned for nine years. In his time the holy Bishop Cuthbert died in the island of Medcaut. $\mathrm{He}$ it is that made war against the Picts and fell therein.'

18. In the account of the 'Marvels of Britain,' Nennius's topography is mainly Welsh, and for the most part South Welsh, but there is one passage connected with the North, namely, that referring to Loch Lomond, known in Welsh as 'Llyn Llumonwy' (in Nennius spelt 'Lumonoy'). Of this 
it is said, 'There are in it sixty islands with people living on them. It is surrounded by sixty rocks, and on each rock there is an eagle's nest. Sixty rivers flow into it, but there is only one, namely, the Lemn (Leven) that flows from it into the sea.'

It can hardly be doubted from these references that in Nennius there are materials derived from Brythonic tradition. It is greatly to be regretted that the most distinguished British historian of the pre-Norman period, Bede, did not take a more sympathetic interest in the northern Britons of his time and the form of Christianity which was associated with them. His references to the Britons of the North are extremely scanty. These are the references which seem relevant to the present question.

1. Bede distinguishes between the languages of the Picts, the Scots, and the Britons. He refers to a 'ciuitas Brettonum munitissima usque hodie, quæ vocatur Alcluith; ad cuius videlicet sinus partem septentrionalem Scotti quos diximus aduenientes sibi locum patriæ fecerunt.' The 'ciuitas' in question is Dumbarton on the Clyde (Irish, Dun Brettan, the fort of the Brittons). The form Alcluith which we have here is apparently derived from the Irish form of the name, but in another manuscript of Bede (of the eighth century) we have the genuine British form of the name Altclut (in modern Welsh Allt Clud, the height of the Clyde).

2. In Bk. x. c. xii., where Bede speaks of the Picts, he refers to an ' urbem Giudi.' His words are 'Orientalis habet in medio sui urbem Giudi, occidentalis supra se, hoc est ad dexteram sui, habet urbem Alcluith [alcluit C. cluit C.B.N.] quod lingua eorum significat petram Cluith.'

3. It is in this chapter, too, that Bede's well-known reference to Peanfahel, near Abber curnig, is found. 'In English,' he says, 'it was called Penneltun, and stretching towards the east it ends near the city of Alcluith [C. alcluit : N. altcluit].' This passage has given rise to no small controversy in relation to the Pictish question.

4. In Bk. II. c. v., Bede refers to the invitation of Hengist, who was invited by Vortigern and his son Oisc. 
5. In Bk. II. c. xiv. Bede refers to the baptism of Edwin, which took place at Easter in 627. He was baptized, according to Bede, at York by Paulinus. On this head there is, as between Nennius and the Welsh Annals on the one hand and Bede on the other, a conflict of evidence, which probably represents a conflict of two church traditions. Paulinus is represented by Bede as baptizing at a river Glein and at a place called Maelmin. Further, he mentions a river in Deira called Sualua, which flows past the village of Cataracta.

6. In Bk. III. c. iv. Bede mentions the conversion of the Picts by Nynias (Ninian, Welsh Nynnyaw), and also the later mission of St. Columba in the reign of Brude, son of Meilochon (Mailchon).

7. In Bk. IV. c. xxiv. (xxvi.) Bede deals with the decline of Northumbria, 'Ex quo tempore spes cœpit et uirtus regni Anglorum "fluere ac retro sublapsa referri." Nam et Picti terram possessionis suæ, quam tenuerunt Angli, et Scotti, qui erant in Britannia, Brettonum quoque pars nonnulla libertatem receperunt : quam et hactenus habent per annos circiter xlvi.'

Among the kings of the Picts Bede (v. 21) mentions a certain Naiton. This name is of interest owing to its resemblance in form to the Welsh Nwython, which corresponds to the Gaelic Nechtan. It is one of several names of Picts to which there are parallels in Welsh, such as Gurgust (the Gorwst or Grwst of Llan Rwst), Bili (Welsh Beli) the father of Brude, Wit (a name found in the Gododin), Drost or Drosten (found in Welsh legend as Drystan, the Tristram of the Romances), Ougen (the Welsh Owein), Mailcon (Welsh Maelgwn), Alpin (Welsh Elphin), Constantin (Welsh Custennhin, now Cystenyn). The names of those who evangelised them, Ninian and Kentigern, who were undoubtedly Britons, bear names that were well known in Wales as Nynnyaw and Cyndeyrn.

The next body of literature from which we may cull certain allusions which link together the two Brythonic districts now in question are the lives of the saints. These are very far from being historical documents, but they have here and 
there preserved traces of the older annalistic framework in which they were set as local religious legends. The Lives of the Cambro-British Saints contain scarcely any references to North Britain, but we are told that St. Cadoc, a saint of South Wales, undertook a journey to Albania, where he performed certain of his miracles. He is also said to have built a monastery of stone beyond the mount of Bannauc (a name thought to survive in Bannockburn), but the precise spot is uncertain. In the same narrative, too, there is a reference to the 'provincia Liutheami,' by which is possibly meant Lothian.

In the 'Pedigrees of the Saints' (in Welsh 'Achau'r Saint'), contained in the same volume, the mother of Cyndeyrn (St. Kentigern) is said to have been Deny, the daughter of Leudun Luydawc, from the fortress of Eidyn in the North. In another place her name is given as Tenoy; while the mother of St. Beuno of Clynnog in Carnarvonshire is said to have been Peren, a daughter of the same person. This name, Lleuddin, is the same as that of the Lleuddin from whom is derived the Welsh nameLleuddiniawn (the district of Lleuddin) for the Lothians. It is singularly like a Welsh derivative of a form 'Laudinus.' Again, St. Tyssilio, the patron saint, for example, of Meifod in Powys is said to have been the son of a lady called 'Arddun,' the daughter of Pabo Post Prydain, a name which not improbably means 'the Bulwark of Pictland.' Another link with the North in the pedigrees of the saints is supplied by the reference to Brychan, whose grave is located on an island called 'Ynys Brachan,' said to be near Mannia. By Mannia is probably here meant the northern Mannia or Manaw. The same place seems also to be meant by Monia, when we are told that 'Dewyn filia Brachan est in Monia Anglis.' There was in all probability a district called Brecheiniauc in the North, and legends of two or more different Brychans (the name being fairly common) appear to have been here iused together.

The lives of the two chief Scottish saints that contain allusions to the Britons of the North are those of St. Ninian and St. Kentigern. Ninian was called by Bede Nynia, by 
Alcuin Nynia, Ninia, and Nyniga; in Welsh he bears the name Nyniaw and in Irish Monenn, 'mo' being the usual prefix of endearment. The place of St. Ninian's birth seems to have been somewhere on the coast of the Solway Firth. The form 'Ninianus' shows the suffix -nus, for which the Britons seem to have had a liking when forming Latin derivatives of proper names. We find it, for example, in the form Caunus, the Latin name of Caw, and in all probability in the name Iaconus, found in the genitive Iaconi on an inscribed stone at Treflys near Portmadoc in North Wales. The life of St. Ninian (c. iv.) mentions the healing of a certain King Tudwal, a name familiar in Welsh genealogies and the basis of the parish-name Tudweiliog (the district of Tudwal) in the Lleyn peninsula of Carnarvonshire. This name in its Goidelic form was Tuathal or Tothal, from an original Touto-uallos. $\mathrm{He}$ is mentioned by Adamnan as the father of Roderc (the Welsh Rhydderch), King of Dumbarton. Among the Welsh names connected with Northern tradition it seems to be possible to distinguish two groups, one connected with the district round Caer Alclud (Dumbarton) on the West and the other connected with the district round Dineiddin (Edinburgh) on the East. In c. xv. reference is made to a son of Rhydderch called Totail, a form of the name modified from the Goidelic Tothal.

In theVita Kentigerni auctore Jocelino Monacho Furnesensi there are a few references which link together North Wales and North Britain. The parish church of St. Asaph in Denbighshire is dedicated to SS. Asa (Asaph) and Cyndeyrn (Kentigern). It is generally believed that the Kentigern of St. Asaph and the Kentigern of Glasgow were one and the same person. St. Kentigern, according to his biographer, had another name, Mungo, or, as given in the biography, Munghu, thought to be the equivalent of ' $m$ wyngu' (gentle and dear). The life as we have it appears to be based to some extent on Celtic documents, in part at least in Irish Gaelic. The narrator refers to material he had found 'in poeticis carminibus sive historiis non canonicis.' 
St. Kentigern was associated with Dumpelder, a part of the Lammermuirs in the county of Haddington, now called Traprain Law. In the older life his birthplace is said to have been called Kepduff, now Kilduff. On the hill of Dunpilder, St. Monenna or Darerca is said to have founded one of her seven Scottish churches.

The name 'Cyndeyrn' is explained in the life as 'Capitalis Dominus,' 'capitalis' being used in the sense of 'prominent,' which 'cyn' as a prefix might well bear. Munghu, his other name, is explained as 'Karissimus amicus,' a free translation of the name regarded as the equivalent of the Welsh mwyngu. A Celtic place-name Carnock (Gaelic Cernach), mentioned in St. Kentigern's life as being in the parish of St. Ninian's in Stirlingshire, is probably Brythonic, being an adjective from carn (a cairn). The old name of Glasgow, too, is given in the following passage: 'Usque ad Cathures que nunc Glasgu vocatur, itinere recto, Kentigerno cum pluribus se comitantibus sequente pergebant; ibique juxta cemiterium quoddam a sancto Niniano quondam consecratum, cum sacrae glebæ sarcina superimposita, pulchro satis spectaculo, cum omni mansuetudine subsistebant.'

In c. xi. there is a specific reference to Kentigern's journey to Wales. As to what occurred there we are told 'Instinctu ergo divino rex et clerus regionis Cambrensis cum cæteris Christianis, licet perpauci essent, in unum convenerunt.' In this chapter also the country of the Northern Britons is called 'regio Cambrina.' 'Hæc autem regio Cambrina, cui jam Kentegernus episcopali præfuit honore, quondam tempore Eleutherii Papæ, principante rege Lucio, sicut et tota Britannia, fidem Christianam susceperat.' Some of the proper names are not easy of identification. The name Morken, mentioned in cc. xxi. and xxii., may be that of Morcant (mentioned by Nennius). The name of the river Clyde is given in a Brythonic form as Clud, and similarly that of Dewi (St. David). The writer also gives correctly the pre-Norman form of the name 'Nantcarfan' as Nantcarban in Glamorganshire, and the name Riderch is only slightly inaccurate as 
Riderech. On the other hand, the spelling of the name Cadwallon as Cathwallan seems to show Goidelic influence, and the same may be the case with that of Cathen, a soldier of Morken. Its Brythonic form in the pre-Norman period would probably have been Catgen (later Cadyen and Cadien).

In the lives of the Breton saints there is scarcely anything that has a bearing on the relations of Wales and the North. Gildas is correctly stated to have been the son of Caunus (Caw), but he is said in one place to have been born in Cornwall, and in another to have been born in 493 at Arcluyd (Dumbarton). In the life of St. Hervé reference is made to a lady called Rivannone who was near a fountain. The resemblance between this name and that of Rhiannon deserves attention.

In the Middle Ages it was the practice to embody all history and a large body of legend in the form of pseudohistory in the annalistic framework that was transmitted from Eusebius and Jerome to later writers. British writers took special delight in expanding and developing those meagre references which the annalistic framework contained to Britain. The most notable expansions of these annalistic allusions on the Welsh side are the Historia Regum Britannia (written in Latin, and translated into Welsh) of Geoffrey of Monmouth, and the Mabinogion, which, in their present forms, imply a chronological framework of the same type. The proper names found in the allusions which the traditional annals contain to Britain and to the Celts, with the help of genealogies and local legends, became most useful nuclei for pseudo-history. Bran could be identified with Brennus, Beli with Belgius and (Cuno-)belinus, Caswallon with the Cassivellaunus of history, Elen Luyddawg with Helen the mother of Constantine, Macsen Wledig with Maximus, and names from the genealogies could be used without a careful regard for chronological or topographical exactitude to fill up the gaps of history. The methods of Geoffrey and of the Mabinogion are very much the same, except that the Mabinogion have drawn upon a richer store of Welsh local legend. 
As might be expected, there are some Northern references in Geoffrey and in the Mabinogion, but, when these collections of legend were made, Wales had long since lost a living interest in the Britons of the North, and even Cunedda is given as the name of a prince of Cornwall. Similarly Dyfnwal Moelmut is represented as the son of Clutno, prince of Cornwall, though the very name Clutno is undoubtedly Northern, meaning, as it does, the man familiar with the Clyde (Clut + gno). It is a name of the same formation as Mochno (skilled in swine), Tudno (skilled in the land), Machno (skilled in hostages), Tangno (skilled in peace), and Gwyddno (skilled in wood). A certain Stater is styled 'King of the North,' and there is associated with Dumbarton a certain Elidyr, who leaves to Peredur 'the Earldom of the North.' In Geoffrey the name Nynnyaw is given as that of a son of Beli Mawr fab Manogan. Howel ap Emyr Llydaw is said in one place to have been left at Caer Alclud (Dumbarton) when ill and burdened with old age. In connection with the family of Kynvarch, one of the most famous of the Northern families of Wales, Lleu, son of Kynvarch, is represented as receiving for his domain Lodoneis (the Lothians), Uryen as obtaining Rheged (which Geoffrey in another passage says was called Mureif), and Arawn, as being lord of Ysgotlont, that is, the country of the Scots or the Goidels of Scotland. In one passage Arthur is said to have made an expedition from Dumbarton as far as Mureif, 'the land that was called by another name Rheged, against the Picts and the Scots, who before that had fought against Arthur.' These escaped to Llyn Llumonwy (Loch Lomond). Lleu of Lleuddiniawn (Lothian) was, according to Geoffrey, married to Arthur's sister and was the father of Medrawt and Gwalchmai (the Modred and Gawain of the Romances). Geoffrey tells us, too, that Medrawt obtained the help of the Picts and Scots against Arthur. Thus, in the Arthurian story of Geoffrey, there are distinct traces of northern elements.

In the other great Welsh expansion of the annalistic framework to which reference has been made, namely the 
Mabinogion, the traces of Northern British elements are for the most part only slight and incidental. In the 'Four Branches' the legends are nearly all connected with placenames in Wales, but some of the names have analogues in the northern groups. For example, one of the warriors mentioned in the Gododin bears the name of Pwyll, and a Pryder (though not a Pryderi) seems to be mentioned in the Gododin in the expression Lliaws Pryder (the host of Pryder). In the mediæval triads there is a Pryder ab Dolor Deifyr a Bryneich (Pryder son of Dolor of Deira and Bernicia). With Arawn, King of Annwn, may be paralleled Arawn, son of Kynfarch, whom Geoffrey associates with the land of the Scots. Manawyddan fab Llyr is undoubtedly the same person as Manannan mac Lir, but in an Arthurian poem of the Black Book of Carmarthen he is associated with the North under the names Manawidan and Manauid. It would not be strange if, in the legends of the Northern Britons, he was regarded as connected with Manaw or Manann (cf. Clackmannan and Slamannan), a name surviving in Dalmeny, the ancient Dun Mannin. Again, the name Lleu (Llew Llawgyffes) is found in the genealogies as that of a brother of Uryen, and in another genealogy there is a Louhé (i.e. Lleu Hen) son of Guitgé (i.e. Guitgen, later Gwydyen), a name found in the Gododin. Possibly these two personages were later associated with the Lleu and Gwydion of Gwynedd local legend, whose names survive in Din-lleu, Nant-lleu, Bryngwydion and Moel-gwydion. Taliessin, whose name occurs in Nennius, is mentioned once only in the 'Four Branches.' The story of Macsen Wledig in its present form has no links with the North, but in the annalistic framework Helen was connected with York. Again there are no Northern elements in the present story of Lludd and Llevelys, but in the story of Kulhwch and Olwen Lludd's daughter Creurdilat (the Cordelia of Geoffrey) is distinctly connected with Northern legend. It is not impossible, too, that Llevelys is due to a palæographical error for Llevelyd (Lliwelydd), a name invented from Caer Liwelydd (Carlisle). A similar mistake VOL. IV. 
of 'Arderys' for 'Arderyd' occurs in the Red Book Triads.

In the story of Kulhwch and Olwen, which has received rather less recasting than the 'Four Branches,' the traces of Northern elements are more numerous. These may, for the sake of convenience, be enumerated as follows :-

1. The name of Kulhwch and that of his father Kilyd occur in the old poetry of the Red Book of Hergest in Northern associations.

2. The name of the father of Kilyd is given as Kelydon Wledic (Celyddon the Over-lord). This name Kelyddon appears to be invented from Coed Celyddon, the regular Welsh name for the Caledonian Forest.

3. Kulhwch is related to Arthur, who, in one form of his legend at any rate, has northern connections.

4. The names of Arthur's comrades, Kei and Bedwyr (Kay and Bedivere), are associated with the North in an Arthurian poem of the Black Book of Carmarthen.

5. The name Kyndilic (Cyuarwyd) occurs in one of the Llywarch Hen poems.

6. The name of Nudd, the father of Gwyn and Edern, is found in Northern groups: cf. Nudd Hael and Senyllt.

7. With the name of Bratwen and that of Moren Mynawc his father we may compare the Gododin names Bradwen and Moryen.

8. The name Annwas Adeinawc occurs in the Arthurian poem of the Black Book of Carmarthen in Northern associations.

9. With the names of Twrch mab Peris and Twrch mab Annwas we may compare the name of Twrch that occurs in Gorchan Kynvelyn and the poetry of the Red Book of Hergest in association with northern names.

10. The mention of $\mathrm{Caw}$ and his children may be noticed.

11. Reference is made to Dunart Urenhin y Gogled (King of the North).

12. The names of Run fab Nwython, Eidyol, Cyfwlch, Cludno Eidin and Uryen Reget generally occur in northern connections. 


\section{WALES AND THE BRITONS OF THE NORTH 147}

13. There is a passage in which reference is made to Creidylat (Cordelia), daughter of Lludd Llaw Ereint, 'the greatest maiden that ever was in the three islands of the mighty and their three adjacent isles.' 'And for her Gwythyr, son of Greidawl, and Gwynn, son of Nudd, fight every first of May for ever till the Day of Judgment.'

14. There is a reference to the two oxen called 'Deu ychen bannawc,' of which it is said that one is on this side of ' $y$ Mynyd Banna6c,' and the other on the other side. 'And these are Nynnya6 and Peiba6 whom God turned into oxen for their sin.' In the Life of St. Cadoc 'Y mynyd banna6c' is said to be in the North.

15. There is a reference to the mead-horn of 'g6lga6t gogodin,' apparently the same person as 'g6lyget gododin' mentioned in the Gododin itself.

16. With the name Odgar, son of Aed, may be compared the Odgur mentioned in Gorchan Maelderw.

17. Allusion is made to a certain Cado o Prydein, under whom were the sixty 'cantrefydd' (hundreds) of Prydein (Pictland).

18. The name of Mabon vab Modron occurs in an Arthurian poem of the Black Book of Carmarthen in northern associations.

19. There is a further fragment of the Creidylat legend as follows : 'A little before that Creidylat, daughter of Lludd Law Ereint, went with Gwythyr, son of Greidawl. Gwynn, son of Nudd, came and took her by force. Gwythyr, son of Greidawl, collected a host and came to fight with Gwynn, son of Nudd. Gwynn was victorious. And Greit, son of Eri, and Glinneu, son of Taran (thunder), and G6rg6st Letlwm and Dyfnarth his son were taken. And he took "o penn," son of Nethawc, and Nwython and Cyledyr Wyllt (the Wild) his son. And he slew Nwython and took out his heart and compelled Kyledyr to eat his father's heart, and owing to that Kyledyr went into the wilds. Arthur heard that and went as far as the North, and he summoned to him Gwynn, son of Nudd, and set free his nobles with him from his prison 
and made peace between Gwynn, son of Nudd, and Gwythyr, son of Greidawl. And peace was made on the understanding that the maiden should be left in her father's house after being the companion of both, and every first of May for ever until the Day of Judgment Gwynn and Gwythyr should fight from that day forth, and the one of them who should be victorious on the Day of Judgment could take the maiden.'

20. The name of 'Mabon ab melld' occurs in the Arthurian poem of the Black Book of Carmarthen in northern connections.

21. The connection between Arthur and the Cordelia story is further referred to, where it says that 'from thence Arthur went to the North and caught Kyledyr the Wild.'

22. There is a reference to Caw of Pictland in the following narrative: 'And $\mathrm{Ka} 6$ of Prydyn [Pictland] mounted Llamrei, Arthur's mare, and met it (the Twrch Trwyth) when he was at bay. Then Kaw of Prydein took a strong axe and vigorously and nimbly he came to the boar and clave its head into two halves. And Kaw took the tusk.'

23. A further reference to a similar legend occurs in the words, "Arthur said, Are there any of the "anoetheu " [objects difficult of attainment] still unobtained?' One of his men answered, 'Yes, the blood of the exceeding black witch, daughter of the exceeding white witch from the head of the Valley of Pain in the wild land of Hell.' Arthur started towards the North, and came to the place where was the cave of the witch, and Gwynn, son of Nudd, and Gwythyr, son of Greidawl, advised that Kacmwri and Hygwyd, his brother, should be set free to fight with the witch.

24. There is a further allusion to Kaw of Pictland in the words, "And Caw of Pictland took the blood of the witch and kept it with him.'

It is evident from these allusions that there are in this narrative traces of northern elements with which others have been in course of time incorporated. The narrative suggests that Caw of Pictland may have been far more prominent 
in the legends of the Britons at one time than their later forms might lead us to suppose.

In the story called The Dream of Rhonabwy, which was probably written in its present form in the monastery of Ystrad Marchell (Strata Marcella), near Welshpool, in Montgomeryshire, some of the proper names mentioned are drawn from groups associated with the North. For example we have-(1) Iddawc Cordd Prydein (Iddawc the disturber of Pictland); (2) Gwarthegyt, son of Kaw ; (3) Elphin, son of Gwyddno ; (4) Owein, son of Uryen ; (5) Gures, son of Reget ; (6) Edyrn, son of Nud; (7) Mabon, son of Modron; (8) Peredur Paladyr Hir; (9) Dyrstan (Drystan), son of Tallwch; (10) Moryen mana6c; (11) Llacheu, son of Arthur; (12) Adaon, son of Taliessin ; (13) Gildas, son of Kaw.

The Romances of Owain and Luned, Peredur and Geraint and Enid, which correspond to the Yvain, Perceval and Érec et Enide of Chrétien de Troyes, represent phases of the Arthurian legend in too developed and non-local a form to enable us to assign to any elements a Northern colouring. The only links are in some of the names, such as Owein ab Uryen, Cynon ab Cludno Eiddin and Peredur, whose father, Efrawc, is said to have possessed the earldom of the North. At the end of Owein and Lunet there is a reference (also found in Bonedd Gwyr y Gogledd) to the three hundred swords of the family of Cynvarch, who are sometimes known in Welsh collectively as 'Kynverching.' Cynon ab Cludno Eiddin's fame, like that of Caw of Pictland, was obscured in later Welsh literature, but in the earlier literature he has the distinction of being the chief hero of the Gododin, a poem commemorating the battle of Catraeth in the North.

The sediment of some of the older Brythonic legends has found its way, not only into the Mabinogion, but also into the Triads. These are allusions to famous incidents and personages arranged in groups of three. The oldest Triads that Welsh possesses in point of date are 'Trioedd y Meirch' (the Triads of the Horses) found in the Black Book of Carmarthen, but other Triads probably equally old are found in the MS. 
called the Red Book of Hergest. In close association with the Triads in the latter MS. is a story entitled 'Pan aeth llu i Lychlyn' (when a host went to Scandinavia). This story has clear affinities with the Brut of Geoffrey of Monmouth, and in it we are told, 'And when Medrawt heard that Arthur's host was divided he returned against Arthur and joined Englishmen and Picts and Scots with him to keep this island from Arthur.' In the Triads Arthur is chiefly associated with members of the same groups as are found with him in Kulhwch and Olwen and the Arthurian poems of the Black Book of Carmarthen.

In one Triad we are told of the 'Three Horse-loads of the Isle of Britain,' one of which is said to have been that of ' $\mathrm{Du}$ y moroed, the horse of Elidyr Mwynvawr, which brought seven persons and a half on its back from Penn Llech Elidir in the North as far as Penn Llech Elidir in Anglesey. And these were the seven persons, Elidyr Mwynvaur and Eurgein, daughter of Maelgwn, his wife, and Gwynn Da Gyved (Gwynn of the excellent carousal), and G6yn Da reimat (probably a mistake for keimat, warrior), and Mynach Na6mon, his counsellor, and Petryle6, the attendant, his cup-bearer, and Aran Uagyl, his servant, and Albeinwyn, his cook, who swam with his hands on the hindquarters of his horse, and he was the half person.' It may be noted that the next horseload was also connected with the North, 'And the second horse-load was borne by Coruann, the horse of the sons of Eliffer Gosgordua6r (Elifer of the Great Retinue), who carried upon him Gwrgi and Peredur and no one overtook him but Dinogat, son of Cynan Garwynn (the white-thighed), upon the fierce and swift horse, and Aruidiawt, and it won disgrace on account of that unto this day, and Dunawt Fwr, son of Pabo and Cynuelyn Drwsgl (the clumsy) to look upon the funeral pile of the host of Gwenddoleu at Arderyd.' The battle of Arderyd was a famous northern battle fought between the forces of Gwenddoleu and Rhydderch Hael.

Another Triad refers to the two famous battles of Catraeth and Arderydd as follows: ' The three gentle retinues of the Isle 
of Britain, the Retinue of Mynyddog Mwynfawr at Catraeth, and the Retinue of Dreon Lew (the Valiant) in the battle of Arderys (a mistake for Arderyd).' To the same cycle belong the Triads that follow.

1. 'The three monarchs of Deira and Bernicia, and they were three bards, and the three sons of Dissyuyndaut who wrought the three excellent slaughters:-Diffeidell, son of Dissyuyndawt, who slew Gwrgi Gar6lwyt, and that man used to slay a Welshman daily and two every Saturday to avoid killing one on Sunday; Scafynell, son of Dissyuyndawt, who slew Edelfflet Ffleissa6c, King of England; G6all, son of Dissyuynda6t, who killed the two birds of G6endoleu which were keeping his gold and his silver, and they used to eat two men daily for their dinner and twice as many for their supper.

2. 'The three passionate men of the Isle of Britain who wrought the three evil slaughters: Llofuan Llaw diffro who slew Uryen, son of Kynuarch, Llongat Gr6m Uargot of Eiddin, who slew Auon (Auaon), son of Taliessin, and Heiden, son of Euengat, who slew Aneirin G6a6tryd (of fluent song), the king of bards. The man who used to place a hundred head of cattle every Saturday in a bathing vessel in Talhaearn struck him with an axe made for cutting fuel, and that was one of the three blows with an axe.'

3. 'The three battle-graved men of the Isle of Britain. Selyf, son of Cynan Garwyn, and Afaon, son of Talyessin, and G6alla6c, son of Lleena6c. And the reason why they were called "Battle-graved men" was that they avenged their wrong from their graves.'

4. "The three bulwarks of battle of the Isle of Britain : Duna6t, son of Pabo, and Cynuelyn Drwsgl, and Uryen, son of Cynuarch.'

5. 'The three generous ones of the Isle of Britain, Rhydderch Hael, son of Tutwal Tutklyt, and Nudd Hael, son of Senyllt, and Mordaf Hael, son of Serwan.'

6. In the Triad entitled 'The Three Valiant Ones of the Isle of Britain' we have a reference to the three sons of a certain Gleissiar from the North. 
7. The Triad of the three gentle kings of the Isle of Britain also mentions Northern characters, and along with them Mana6ydan, son of Llyr. The other two are Llywarch Hen, and G6gon G6ron, son of Peredur son of Eliffer.

8. In one Triad which names the 'Three Pure Households of the Isle of Britain,' there is named as one household that of the Scot Aedan, son of Gabran, and as another that of G6endoleu, son of Keidya6 (Ceidio) at Arderyd, who kept up the fighting for a fortnight, and a month after their lord was slain. And the number of each of the households was a hundred and twenty-one men.'

9. In addition to the foregoing Northern allusions the following may be given, 'Three kings sprang from serfs: Gwryat, son of Gwryan, in the North, and Cadauel, son of Kynued6, in Gwynedd, and Hyueid, son of Bleidic, in the Deheubarth (South Wales).'

\section{( $T o$ be continued.)}

\section{TANNAISG NAN LAITHEAN A DH'FHALBH}

A bhana-charaid ionmhuinn,

Am faca sibhse riamh an rud sin ris an abair sinn tannasg? Theagamh nach 'eil sibh a' creidsinn 'na leithid. Cha mho a bha mise uaireigin de'n t-saoghal, 's bha mi a' cur spleadhachas mu bhocain, 's mu shithichean, 's mu ghnothaichean mi-chneasda mar sin an suarachas. A bhàrr air sin, bha mi, iomadh uair, 'gam chur fein as mo ghabhail, dìreach a leigeil ris cho beag suim 's a bh' agam de 'n bhathar shith sin. Chrath daoine bu shine 's a bu ghlice na mi-fein an cinn, 's chuir iad air mhanadh gu 'n éireadh olc dhomh uaireigin. Ghabh mise mo rathad fein, mar is gnath leis an digridh a dheanamh; ach thig gliocas oirnn le aois ma thig e idir. Oidhche ghaothar gheamhraidh, 's nedil dhorcha, ghruamach, a' ruagadh a chéile air aghaidh na speur, 's a' doilleireachadh a bheagan a bh' ann de 'n ghealaich, dh'fhalbh mi a dh'fhaicinn caraid domh a bha mu thuaiream mile gu leth a dh'astar uam. 